Ing. Pavel Zona, Ph.D., Ing. Vlastimil Galatík, CSc.

Měnící se role civilně-vojenské spolupráce ve společných operacích NATO a pod národním velením

Vojenské rozhledy, 2013, roč. 22 (54), č. 1, s. 76-88, ISSN 1210-3292

\title{
Civil-Military Cooperation: Its Changing Role in Combined NATO Operations and Under National Command
}

\section{Abstrakt:}

Role civilně-vojenské spolupráce (CIMIC) v postmoderních válkách (operacích) vzrůstá. CIMIC je významným prvkem koordinace aktivit vojenských a civilních aktérů vojenské operace. Úkoly, které pro tuto složku vyplývají ze současné konсерсе NATO, kladou šíri jejího záběru do nové dimenze. V armádách, jako je i Armáda České republiky, je nutno řešit celou řadu problémů spojených s tímto zadáním. Článek nastiňuje možný soubor činností spojených s novým př́stupem k CIMIC v rámci krizového managementu v AČR a v kontextu jejího působení $v$ rámci Aliance i pod národním velením.

\section{Abstract:}

The role of civil-military cooperation (CIMIC) is increasing in the post-modern wars (operations). CIMIC is a significant element at the coordination of military and civilian participant activities over current military operations. New tasks for actors are a result of the current new NATO concept and outline the new tasks dimension. The armed forces as well as the Army of the Czech Republic have to solve many problems associated with this new dimension. The article outlines a possible set of activities associated with the new approach to CIMIC in crisis management in the context of the Alliance operation.

\section{Klíčová slova:}

Civilně-vojenské spolupráce, CIMIC, nová koncepce NATO, aktivní angažovanost, moderní obrana, krizový management, integrovaný záchranný systém, alianční operace, národní velení, komplexní přístup, CA.

Key words:

Civil-military cooperation, CIMIC, new NATO concept, Active Engagement, Modern Defence, crisis management, integrated rescue system, Alliance operations, comprehensive approach, CA. 


\section{Úvod}

Prostředí, ve kterém jsou vedeny války a do kterého jsou nasazovány ozbrojené síly, se od závěrečných desetiletí dvacátého století významně změnilo. Do té doby se války a další operace vedly v převážně vojenském, trojrozměrném prostředí a v prostoru do značné míry otevřeném. Tato situace skončila poslední moderní válkou, což byla válka v Perském zálivu v roce 1991, konkrétněji operace Pouštní bouře. [1] Všechny následující války, konflikty i operace, měly zcela zásadně odlišný charakter a začíná se hovořit o postmoderních válkách, asymetrických operacích, konfliktech a podobně. Mnohem četnější je také použití ozbrojených sil v humanitárních intervencích za řízení jiných složek státu. Ukazuje se, že současné a pravděpodobně i budoucí operace se odehrají za situací, ve kterých bude prostředí jejich vedení hrát roli vyrovnávacího elementu mezi nesouměřitelnou západní technologickou převahou a relativně jednoduchými technologiemi všech možných uvažovaných protivníků. Půjde o prostředí tvořené obyvatelstvem, především pozemní a relativně uzavřené prostory městských aglomerací a hustě zalidněných oblastí nebo terénem, kde je využitelnost technologické převahy přinejmenším diskutabilní. Obdobně i intervence s humanitárním cílem budou vedeny $\mathrm{v}$ tomto prostředí.

Schopnost CIMIC je již dnes nedílnou, uznávanou a respektovanou součástí širšího spektra schopností moderních armád. Pokud má být i armáda rovnocennou součástí sil NATO, nemůže se ČR zbavovat spoluzodpovědnosti za realizaci politických rozhodnutí a podílu na schopnosti Aliance řešit krize kdekoli je to nezbytné.

Základním dokumentem, ze kterého vychází následující závěry, je nová strategická koncepce NATO př̉jatá v roce 2010 na summitu v Lisabonu nazvaná Active Engagement, Modern Defence. Pro vedení armády je v této oblasti jednoznačně nejdůležitější a zásadní pasáž, ve které jsou vytyčeny změny v přístupu ke krizovému řízení v NATO $\mathrm{s}$ tím, že problematika CIMIC musí procházet celým spektrem aktivit spojených s krizovým plánováním. Úkoly, které jsou v tomto dokumentu vyjmenovány, se týkají celé organizace a všech jejích národních armád.

\section{Prostředí současných operací}

Zcela zásadním závěrem, který lze učinit, je, že se typickými, ale nikoli jedinými zónami střetů a intervencí stávají převážně města. Ozbrojené síly dnes působí hlavně v zalidněných prostorech. Obydlené lokality nahrazují otevřený terén a stávají se základními prostory činnosti. Úspěch ve „válce ve městě“ se stal závislý na novém zpơsobu použití ozbrojených sil. To však znamená hluboce pochopit, že nelze vyhrát válku s městem, ale pouze válku v myslích obyvatelstva ve městě. Toto pravidlo, tak jako každé, neplatí vždy. Například v Iráku komplikovalo situaci široké spektrum zájmů a zájmových skupin obyvatel. Již v 5. století před naším letopočtem fillozof a historik Thukydides moudře zmiňuje: „Lidé to jsou, kdo tvoří obec (město), nikoli zdi.“ Tento citát neztrácí nic na své hloubce v případě jakéhokoli nasazení ozbrojených sil, at už je jeho cíl vojenský nebo humanitární a vojska jsou zasazována doma nebo v zahraničí.

\section{Válka v prostředí obyvatelstva}

Současné a s vysokou pravděpodobností i budoucí války, konflikty a další možná zasazení ozbrojených sil se nebudou odehrávat jen jako konflikt či interakce „mezi“ 
společnostmi, ale především jako konflikt ,v rámci“ společnosti. Obyvatelstvo se tímto stává účastníkem a z vojenského hlediska i hlavním problémem postmoderních válek. Jen stěží lze nalézt konflikt, kde by se civilní obyvatelstvo neocitlo v jádru vojenského zájmu zúčastněných stran. Tím je překonán model, ve kterém obyvatelstvo tvořilo „zázemi““, jako protějšek fronty, tedy čistě vojenské zóny. Ozbrojené síly nyní působí bezprostředně mezi obyvatelstvem a ve značné závislosti na něm. Tím vstoupily do období válek vedených $\mathrm{v}$ prostředí obyvatelstva.

Při př́ímém zasazení sil lze z obyvatelstva snadno vytvořit neprátelský dav, který může získat charakter ,armády“, se kterou nelze s ohledem na mandát a platné konvence bojovat. Pokud ale chápeme obyvatelstvo i jako předmět působení, pak musíme zaměřit své aktivity tak, aby jeho reakce vyzněly v náš prospěch. Právě obyvatelstvo se tedy stává bodem konfrontace nebo společenským prostorem, který musí zasazené síly udržet. $Z$ výše uvedeného plyne závěr, že má-li být operace maximálně účinná, je potřebné již při plánování ozbrojených intervencí brát na zřetel politický účinek spojený se situací, která čeká obyvatelstvo uvržené do nepořádku, chaosu nebo bezvládí. Vedení operací př́mo mezi obyvatelstvem má také značnou etickou dimenzi, kde důležitou součást podílející se na konečném výsledku tvoří psychologické působení.

\section{Rostoucí význam pozemního prostředí}

Použití síly je realizováno v podstatné míře v prostoru lidské společnosti, v pozemním prostředí, kde se nalézá základní oblast jeho aplikace. Je to právě pozemní prostředí, kde se rodí a zanikají krize. Je pravděpodobné, že budoucí války, tak jako ty současné, budou nezř́́dka zahájeny na dálku z moře nebo ze vzduchu, ale budou vždy ukončeny na zemi, $\mathrm{v}$ situaci, kdy síly působí přímo mezi obyvatelstvem a v př́mé konfrontaci s „nepřátelskými stranami“. Fyzicky pouze na zemi, kde je zajištěn kontakt se všemi aktéry a nepřetržitá přítomnost sil, mohou přijatá opatření přinášet očekávané výsledky.

V současné době, výrazněji než v minulosti, kdy je v mnohem menší míře cílem akce stát a více samotné obyvatelstvo, znamená ovládnutí prostředí obyvatelstva jednu z podmínek vítězství ve válce. Tedy, ve válce proti protivníkovi, který je téměř vždy neregulérní, je prakticky jediným způsobem řešení situace ovládnutí prostředí na zemi, kde žije obyvatelstvo a působí potenciální (nepravidelný) protivník. Ovládnutí pozemního prostředí v přijatelném čase tvoří jádro a hybnou sílu „stabilizační fáze“ operace, která se stává „rozhodující fází", v níž se vytváří podmínky realizace požadovaného strategického efektu. Tato akce na zemi (ovládnutí prostředí) umožňuje transformaci vojenského cíle do cíle politického. To vyžaduje síly schopné trvalého působení v prostoru konfliktu, schopné rychlé reakce na vývoj podmínek. Uznávaný americký analytik, vojenský historik a teoretik, profesor na US Military Academy ve West Pointu, Frederick W. Kagan je velmi kritický k reálné situaci v teorii a praxi ozbrojených sil a činí tři podstatné závěry:

1. Rozhodnutí rozvíjet metodu války, jejíž úspěch závisí především na identifikaci a zničení cíle spíše než na ovládnutí území, ukazuje základní rozpor povahy samotné války.

2. Velikost pozemních sil potřebných pro ovládnutí území je podmíněna mnohem více rozlohou, hustotou a počty obyvatelstva, než charakterem výzbroje, kterou mají vojska $\mathrm{k}$ dispozici. 
3. Ještě dlouho, pokud válka zůstane interaktivním střetem mužů, což je podstata neregulérní války, bude realizace vojenské moci vyžadovat značné investice do lidí. [2]

V současných, ale i budoucích konfliktech a jiných operačních zasazeních budou muset velitelé citlivě vnímat komplexní a proměnné prostředí, ve kterém působí, což nebude možné v některých fázích konfliktu jiným způsobem, než aktivitami přímo v terénu a v dotyku s obyvatelstvem. To jim umožní použít sílu maximálně efektivně a mít efektivní zpětnou vazbu umožňující i zpětné kroky v organizaci sil dle vývoje a průběhu situací. Přitom musí být také zachována spojitost mezi taktickými a politickými aktivitami. Pravděpodobně ještě více naroste význam specializovaných orgánů (orgánů CIMIC) zajištující veliteli interakci v prostředí obyvatelstva.

Historie nás učí, že pouze pozemní síly mohou být rozhodující silou ve válce, přestože je jasné, že porážka Německa ve druhé světové válce by nebyla možná bez jeho porážky ve vzduchu a v Atlantiku a porážka Japonska bez mohutného amerického lod'stva a letectva by byla jen iluzorní. Přesto vše byla vítězem jen ta strana, jejíž voják vztyčil svůj prapor nad územím neprítele.

Význam pozemních akcí a prostředí tvořeného obyvatelstvem zdůraznil ve svém vystoupení v červnu 2007 na Válečné škole (École de guerre) náčelník štábu pozemních sil Francie, armádní generál Bruno Cuche:

„Je to souhrn taktických činností (pozemních), spíše než soustředěné akce na velkou vzdálenost vedené z moře nebo ze vzduchu, které umožní dosažení požadovaného konečného efektu. Naši vojáci jsou dnes, individuálně i kolektivně, nositeli části strategických účinkủ. Pozemní prostř̌edí je, a v budoucnosti bude ještě více, těžǐštěm vševojskových tažení, protože právě zde se nachází obyvatelstvo. Zasazení pozemních sil pak představuje nejsilnější důkaz politického angažování.“ [3]

Všeobecné charakteristiky budoucí války nebo i nevojenských krizí ústí v poměrně jasný závěr: za aktuálních podmínek sehrávají schopnosti pozemních sil klíčovou roli ve vnější i vnitřní bezpečnosti země. Pozemní síly jsou hlavním nástrojem k udržení pozic země v bližším i vzdálenějším bezpečnostním prostředí, což je dáno jejich schopností jednat a schopností prosadit politickou vůli. Pozemní síly jsou nejvíce vnímány jako síly národní.

Vědomí, že každá krize, i válečná, je nakonec řešena v prostř̌edí tvořeném obyvatelstvem a zpravidla i ve prospěch obyvatelstva, je vnímána i na alianční úrovni, v rovině politicko-vojenské, strategické, operační i taktické. Dokladem toho je i snaha nalézt řešení a s tím spojený rozvoj koncepcí od effects-based operations (EBO), přes effectsbased approach to operations (EBAO) až konečně po comprehensive approach (CA), což je praktická reakce na změněné prostředí vedení operací. Tyto změny se průběžně odrážejí ve stěžejních dokumentech nejvyšších orgánů NATO.

\section{CIMIC - součást krizového řízení}

Krize a konflikty za hranicemi států NATO mohou představovat př́ímé ohrožení bezpečnosti obyvatel a území Aliance. Proto je nezbytné zaměřit pozornost především na předcházení krizím, a teprve následně na jejich řešení, př́ípadně i s využitím ozbrojených sil, či př́ípadnou stabilizaci po konfliktu a na podporu rekonstrukce. Nejlepší způsob, jak zvládat konflikty, je předejít jim. NATO proto musí průběžně sledovat 
a analyzovat mezinárodní prostředí, předvídat krize a př́ípadně přijímat účinná opatření, aby nedošlo k jejich eskalaci.

\section{Rozvoj krizového managementu v NATO}

Na základě zkušeností z operací NATO v Afghánistánu a na Balkáně se ukazuje, že výsledek může přinést pouze propojení komplexního politického, civilního a vojenského přístupu (comprehensive approach - komplexní př́istup), který je nutnou podmínkou pro účinné řešení krizových situací. Aliance, mimo využití široké škály vojenských i nevojenských nástrojů, musí aktivně spolupracovat se všemi mezinárodními aktéry při zpracování společných analýz, plánování a vedení činnosti, s cílem maximalizovat soudržnost a účinnost celého mezinárodního úsilí.

Pokud se úsilí NATO zaměřené na předejití konfliktu ukáže jako neúčinné, musí být Aliance připravena a schopna zvládat rozvíjející se konflikt přímým angažováním. K tomu má odpovídající schopnosti, včetně jedinečné schopnosti nasazení a udržení silné vojenské jednotky v prostoru krize po celou dobu jejího trvání. I když se konflikt daří urovnat a blíží se ke svému konci, musí mezinárodní společenství často poskytovat další dlouhodobou podporu, a tím vytvořit podmínky pro dosažení trvalé stability. V této fázi je Aliance připravena a schopna přispět ke stabilizaci a rekonstrukci v úzké spolupráci a na základě průběžných konzultací s dalšími mezinárodními aktéry.

Pokud má být NATO úspěšné v celém spektru aktivit v rámci krizového managementu je nezbytné:

$\square$ zlepšit vzájemné sdílení zpravodajských informací v rámci NATO tak, aby bylo možno lépe předpovědět, kdy a kde může ke krizi dojít a jak jí nejlépe předcházet,

$\square$ dále rozvíjet vojenské schopností zaměřené na vedení expedičních operací, včetně fází stabilizace a obnovy,

vytvořit odpovídající civilní krizový management, v rámci vojenských štábů, zaměřený na efektivnější spolupráci s civilními partnery (tato schopnost může být také použita k plánování, rozvíjení a koordinaci činností spojených s přenosem některých povinností a úkolů na jiné subjekty dokud to podmínky umožňují),

$\square$ rozvinout integrované civilně-vojenské plánování ve všech fázích a v celém spektru operací,

$\square$ rozvíjet schopnost cvičit a připravovat místní ozbrojené síly tak, aby místní orgány mohly v co nejkratší možné době zajistit bezpečnost bez mezinárodní pomoci,

$\square$ ve všech členských státech identifikovat a připravit civilní odborníky pro rychlé nasazení ve vybraných misích, schopných pracovat s našimi vojáky a s civilními odborníky z partnerských zemí a institucí,

$\square$ rozšírit a posílit politické konzultace mezi spojenci a partnery, a to jak v pravidelných intervalech, tak při řešení př́ipadné krize ve všech fázích. [4]

Takto jsou definovány nejdůležitější výzvy a úkoly stojící před Aliancí i před jednotlivými členskými státy a jejich armádami. V současnosti prochází posledními úpravami novelizovaný AJP-9, tedy Allied Joint Doctrine for Civil-Military Cooperation. $\mathrm{K}$ dispozici je draft č. 2 dokumentu, z něj plynou další úkoly. 


\section{Alianční doktrína pro CIMIC: AJP-9 (draft)}

Je zřejmé, že vyvozovat konkrétní návrhy opatření z pouhého návrhu textu je problematické. Už jen nalezení konsenzu při zpracování konečného návrhu AJP-9 trvalo několik let a není zdaleka jisté, že se jedná o konečnou podobu. Přesto je ale důležité sledovat změny, které s sebou tento dokument nese a být připraven na ně včas reagovat. $\mathrm{S}$ touto predikcí je nezbytné přistoupit k následujícímu textu.

Základní definice CIMIC má dnes následující znění: „Koordinace a spolupráce, na podporu mise, mezi velitelem NATO a civilními aktéry, včetně místního obyvatelstva a jeho přestaviteli, jakož i mezinárodními, národními a nevládními organizacemi a agenturami. ${ }^{6}[5]$

Cílem civilně-vojenské spolupráce je podpora mise vojenským př́íspěvkem v rámci komplexního přístupu v případě, že jsou stanoveny společné cíle pro vojenské a civilní aktéry. Pokud tyto cíle nejsou předem stanoveny, bude CIMIC zabezpečovat harmonizaci a pomáhat v předcházení možných konfliktů mezi vojenskými a civilními složkami, což má základní přínos ve sladění jejich aktivit. V tomto případě je důraz kladen na předcházení duplicity aktivit nebo na vyloučení vzájemně rušivého vlivu, čímž se minimalizuje negativní dopad na podporovanou komunitu. K naplnění tohoto cíle je nutno dosáhnout patřičné úrovně koordinace, vzájemné spolupráce, podpory, koherentního společného plánování a výměny informací.

Pokud se zaměříme na nejdůležitější část tohoto cíle, je jasné, že důraz je nutno položit především na komplexnost spolupráce s civilními aktéry a na rozvíjení vztahů s nimi. Vztahy s civilními organizacemi se v průběhu operace vyvíjí ne vždy požadovaným směrem a kontinuálně, od nespolupráce, přes soužití (koexistenci) až po spolupráci (kooperaci). K tomu, abychom v operaci skutečně uspěli, je ve většině případů nezbytné co nejvíce sladit nebo alespoň přiblížit vojenské cíle a metody s těmi, které mají civilní aktéři. Ve složitých operacích, na nichž spolupracují významné civilní složky a civilní politické orgány, je vojenský operační plán (OPLAN) pouze jedním z několika funkčních plánů. Z toho plyne nutnost společného integrovaného plánování na všech úrovních. CIMIC je potom velitelským nástrojem pro vytváření, udržování a rozšiřování těchto vztahů. [6]

Vzhledem k situaci, kdy se dotváří nová verze AJP-9, po ukončení lisabonského summitu, je evidentní, že reaguje i na obecněji stanovené úkoly pro oblast civilně vojenské spolupráce přijaté ve strategické koncepci.

Vzhledem k naléhavosti plnění úkolů vojsky nelze čekat na konečnou verzi doktríny CIMIC, ale bylo by nanejvýš vhodné a pro další směřování CIMIC v AČR i výhodné připravit se na jejich případnou aplikaci v co nejkratší možné době. Zvláště v současném období, kdy se orgány CIMIC v AČR jako by hledaly. AČR prakticky opustila Kosovo a lze předpokládat postupný útlum PRT v Afghánistánu. Právě toto období je vhodné pro tolik potřebné zásadní změny $\mathrm{v}$ přístupu k práci a vytvoření nových základních dokumentů.

\section{Nutné změny a nové úkoly}

Ve strategické koncepci jsou v pasáži věnované krizovému managementu přesně stanoveny úkoly a potřeba je naplňovat. V rámci CIMIC v AČR se k některým z nich vracíme po více jak deseti letech od jeho založení, a přesto jsou mnohdy považovány 
za zcela nové. V následující části jsou některé úkoly rozebrány a konfrontovány s činností Střediska CIMIC AČR.

\section{Předpokládlané úkoly pro CIMIC v AČR}

Jednotlivé úkoly, které jsou rozpracovány v této pasáži, se netýkají pochopitelně pouze malé roty CIMIC jako součásti 103. střediska CIMIC/PSYOPS, ale celého velení AČR na všech stupních.

1. Zpracování společných analýz, plánování a vedení činnosti, s cílem maximalizovat soudržnost a účinnost celého mezinárodního úsilí.

Obdobný úkol plnilo Středisko CIMIC již v roce 2002, kdy se očekávala reakce mezinárodního společenství na situaci v Iráku. Veškeré volné síly se zaměřily na studium dostupných materiálů o tomto regionu, o jeho vazbách na Českou (Československou) republiku, o aktivitách našich subjektů, na vazby a vztahy $\mathrm{s}$ místní populací s dưrazem na odborníky, kteří byli v minulosti připravováni v našich vzdělávacích zařízeních. Při zpracování analýz pracovníci střediska úzce spolupracovali s Ministerstvem zahraničí a s Ministerstvem průmyslu a obchodu. Výsledkem byla rozsáhlá databáze informací a analýz, kterou středisko mohlo poskytnout nadřízeným v okamžiku, kdy byl vydán rozkaz pro prrípravu a vyslání našich jednotek do oblasti.

Není nic jednoduššího, než na tuto činnost navázat a pomoci naplnit jeden ze zásadních „nových“ úkolů.

2. Aliance musí být připravena a schopna přispět ke stabilizaci a rekonstrukci v úzké spolupráci a na základě prủběžných konzultací s dalšími mezinárodními aktéry.

Zde je na místě si položit otázku: Co víme o našich potenciálních partnerech z řad civilních organizací? Jako odpověd' vyplývá následující skupina úkolů nejen pro středisko CIMIC, ale i pro pracovníky CIMIC na různých stupních velení, včetně GŠ AČR. Tyto úkoly jsou významné i pro velitele brigád a praporů. Především je nutno:

$\square$ zpracovat podrobnou a otevřenou databázi civilních organizací, se kterými AČR (brigáda, prapor) spolupracovala v uplynulém období,

$\square$ prostudovat dostupné informace o dalších civilních organizacích využitelných v rámci konceptu CIMIC a působících na našem území nebo z něj do zahraničí,

$\square$ navázat kontakty (pokud možno osobní) s těmito organizacemi,

$\square$ zahájit výměnu zkušeností a poznatků jako základu pro další rozvoj společných aktivit a stanovit pro ně pravidla,

rozvinout systém společné př́ípravy a výcviku,

$\square$ prohloubit a jasně definovat systém vzájemné výměny informací ve všech fázích činnosti (fázích vojenské operace).

Všechny tyto úkoly, celý soubor opatření, mohou být plněny stejně při řešení krizí v zahraničí, tak i doma při působení AČR v rámci integrovaného záchranného systému České republiky (IZS). 


\section{Dále rozvíjet vojenské schopnosti zaměřené na vedení expedičních operací, včetně fází stabilizace a obnovy.}

Uvedený úkol úzce navazuje na předešlý. Hlavní důraz musí být položen především na schopnost propojit aktivity vojenské s aktivitami civilními. Zde je třeba nezapomínat na základní poslání CIMIC - což je podpora mise - tedy úkolu, který velitel obdržel. Při plnění úkolu nemá velitel vždy k dispozici patřičnou civilní organizaci připravenou jej podporovat. Tady se vracíme k původní roli CIMIC - vytvořit veliteli takové podmínky, které mu umožní splnit jeho úkol, který realizuje $\mathrm{v}$ civilním prostředí. $\mathrm{K}$ tomu je nezbytné mít prostředky, a to jak materiální, tak i finanční. Ukazuje se, že už jen úzká komunita lidí je ochotna s námi spolupracovat za drobné dárky. Úkol se zdá být jasný - zajistit dostatečné prostředky na vedení aktivit podporujících úsilí velitele, tedy především na realizaci projektů s okamžitým účinkem - quick impact projects (QIP). Tím otevř́it cestu k srdcím a myslím místního obyvatelstva.

\section{Vytvořit odpovídající civilní krizový management v rámci vojenských štábů,} zaměřený na efektivnější spolupráci s civilními partnery.

Tento úkol neznamená nic jiného, než naplnit poslání CIMIC v oblasti př́pravy a plánování. Orgány CIMIC, jako integrální, dobře připravená a respektovaná součást štábu mohou tvořit základ nebo významnou složku i civilního krizového managementu. $\mathrm{K}$ dosažení tohoto stavu je nutno naplnit obsah předchozích úkolů, ale i celé řady dalších, které postupně vyplynou z dalšího studia a naplňování „úkolového listu“, za který lze považovat novou strategickou koncepci NATO. Při jejím studiu a naplňování nelze zapomenout na jednu zásadní skutečnost a tou je, že CIMIC nemusí být určen jen $\mathrm{k}$ plnění úkolů na cizím území při alianční operaci, ale může být také využíván při zapojení armády do aktivit IZS při řešení krizí na vlastním území pod národním řízením. A tady se naskýtá celá řada otázek:

Co je úkolem CIMIC v takových situacích?

$\square$ Kde je jeho místo?

$\square$ Má jeho činnost nějaká pravidla?

Ví, s kým bude spolupracovat - zná ho?

$\square$ To jsou jen některé z otázek, které vyplývají ze zkoumání otázek CIMIC v soudobém bezpečnostním a operačním prostředí, ale jistě jich bude postupně celá řada dalších, kdy budou vyvstávat s hloubkou řešení problematiky.

\section{Nutné změny}

Nutnost zásadní kvalitativní změny v konceptu civilně-vojenské spolupráce v AČR je poměrně jasná. Je dána rozšiřujícím se spektrem operací, nevyhovujícími vztahy mezi aktéry či činiteli působícími v prostoru krize. Zdaleka se nejedná jen o vztahy mezi vojenskými účastníky a civilními organizacemi. Situace je mnohem komplikovanější.

Rozvoj spolupráce ve společném prostoru má široké spektrum možností.Zvýšení schopností armád NATO v tomto směru může být dosaženo např́klad prostřednictvím:

$\square$ podpory připravenosti ostatních aktérů, založené na principu dobrovolnosti a př́slušném stupni vzájemného porozumění, 
dosažením nekonfliktnosti mezi účastníky, založené na principu vzájemného sdílení informací, vzájemného respektu a transparentnosti,

přizváním dalších vybraných aktérů ochotných společně pracovat na zvládnutí současných nebo potenciálních krizí cestou společného postupu,

$\square$ dosažením společného postupu na jednotlivých případech založeném na společném plánování a vzájemné shodě dosažené na strategicko-politické úrovni a pokračující na úrovních dalších (nižších).

Tato čtyři pravidla ukazují vlastní podstatu vzájemných vztahů mezi armádami NATO a ostatními aktéry zainteresovanými na společném řešení krize pod hlavičkou OSN. Dílčí vztahy mezi jednotlivými aktéry procházejí celým spektrem vzájemného působení a jsou vždy závislé na typu a stadiu krize. Cesty rozvoje vzájemné součinnosti mohou být následující:

- rozvoj komplexního plánování a sblížení vztahů na pracovní úrovni mezi silami Aliance a vnějšími aktéry již před operací nebo alespoň na jejím samém počátku,

- nalezení společného zájmu soustředěného na prostor zodpovědnosti s cílem prohloubit komplexnost společného úsilí různými nástroji na řešení krize,

- stanovení pevné formy mechanismů vzájemného civilně-vojenského působení na všech úrovních a vytvoření společných celků zaměřených na co nejjasnější stanovení úkolů a odpovědnosti,

- propojení společně stanoveného mechanismu v rámci „crisis response system“ a „operational planning process“ $\mathrm{s}$ aktéry stojícími mimo NATO.

Z uvedeného výčtu úkolů a cest je evidentní, že snaha armád NATO o co nejširiší prohloubení spolupráce $\mathrm{v}$ celém spektru operací je jasně deklarována a současné dokumenty a směrnice NATO ji odrážejí. Je evidentní, že tato pravidla byla koncipována především pro vojenské operace mimo vlastní území. Armády všech členských států NATO však mají funkcí několik. Pro AČR mimo jiné platí, že: „Bezpečnost České republiky zajištujúi ozbrojené síly, ozbrojené bezpečnostní sbory, záchranné sbory a havarijní služby." [7]

\section{Možné aktivity CIMIC při řešení krizí na vlastním území}

V návrhu nové AJP-9A se doslova uvádí: „Př̌i plnění úkolů CIMIC budou jeho př́slušníci vytvářet a udržovat vztahy s civilními aktéry na vhodných úrovních s cílem usnadnit spolupráci, harmonizaci, vzájemné sdílení informací, integrované plánování a vedení operací." [8] Na základě tohoto stěžejního úkolu lze vyvodit, že aktivity spojené s civilně-vojenskou spoluprací nelze chápat pouze jako součásti vojenských operací v rámci NATO, ale obecně vzato jakýchkoli operací, na kterých se armáda podílí. Tedy i při jejím zapojení v IZS.

\section{Pravděpodobné aplikace základního poslání CIMIC}

Jednoduché a relativně dobře známé základní schéma zapojení CIMIC do aktivit v rámci vojenských operací při řešení krizí obecně lze aplikovat na místo a činnosti armády při řešení krizí na vlastním území př̀i operacích pod národním velením. Tady 
je nezbytné podotknout, že v rámci IZS za činnosti odpovídá BRS a orgány krizového řízení krajů, obcí a AČR plní jen pomocné funkce.

Na obr. je aplikováno jednoduché schéma sladění metod a dílčích cílů ke společnému zájmu jednotlivých aktérů. Z obrázku vyplývá místo a úloha CIMIC v rámci IZS při použití vyčleněných sil a prostředků ozbrojených sil (OS). Je soustředěna především na aktivity, na kterých se podílí OS, a to při všech činnostech vedoucích k naplnění jednotlivých dílčích cílů a následně při vlastním vyřešení mimořádné události.

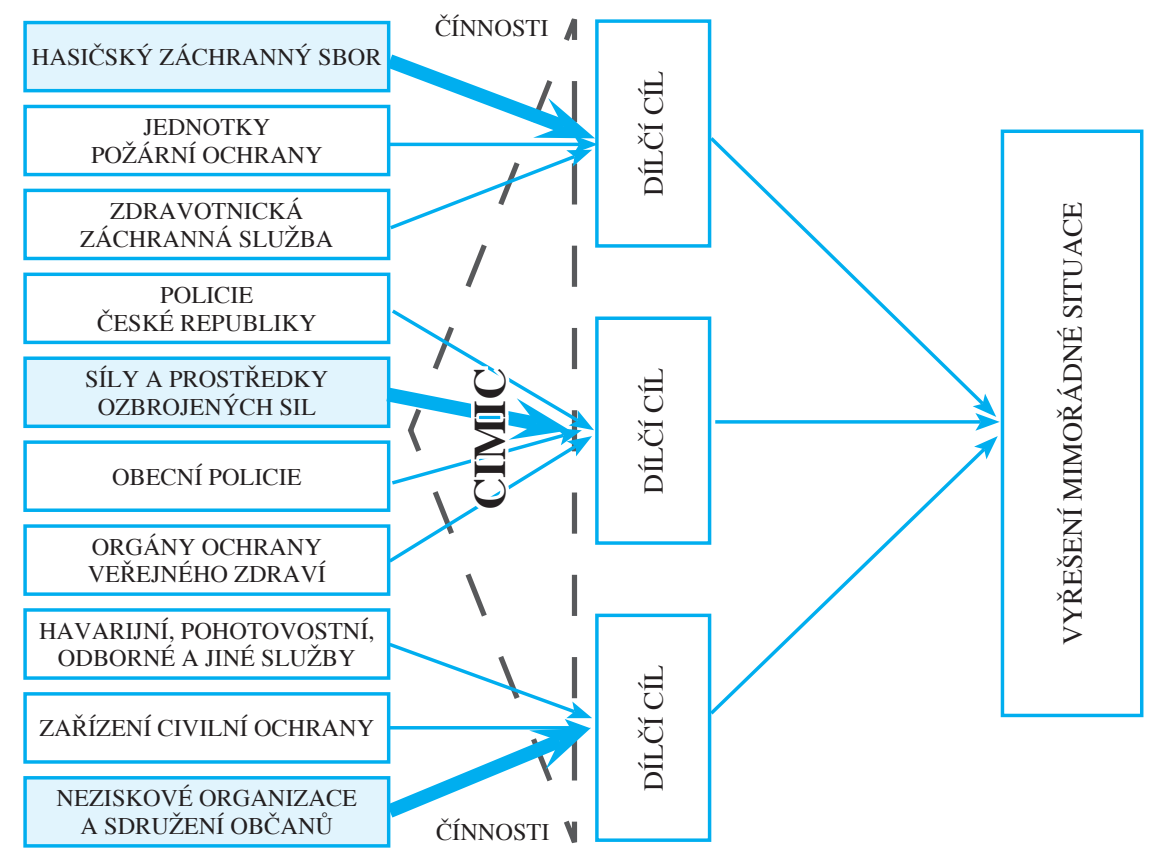

Obr.: Místo CIMIC v rámci zapojení ozbrojených sil do IZS při řešení mimořádné události

K tomu, abychom mohli naplnit jednotlivé dílčí cíle, aby bylo možno plně využít schopností, kterými CIMIC disponuje, je nutné zavést systematickou přípravu a výcvik. Při naplňování požadavků v této oblasti je možné a dokonce nutné vycházet $\mathrm{z}$ aliančních dokumentů, které stanovují cesty rozvoje, kterými CIMIC v budoucnu musí jít.

V dokumentech, které byly citovány v předcházejících kapitolách, je stanoven směr a úkol jak pro oblasti přípravy a výcviku, tak i pro fázi operačního nasazení CIMIC. Tyto úkoly jsou prvoplánově stanoveny pro vojenské operace v rámci NATO. Při vztažení na vlastní území nám vyvstanou úkoly spojené s nasazením CIMIC v rámci vyčleněných sil AČR v rámci IZS. Dokumentovat to lze na několika vybraných př́kladech:

- Dosáhnout většího propojení mezi jednotlivými složkami při plnění dílčích cílů v rámci IZS. Toho lze dosáhnout především pochopením úkolů jednotlivých složek a jejich místa v systému, postupu a metod práce.

- Rozvíjet a zlepšovat každodenní, ale i př́ležitostnou civilně-vojenskou spolupráci a na základě toho rozvíjet mechanismy a procesy umožňující optimalizaci 
spolupráce. Tady se nabízí cesta $\mathrm{k}$ propojení činností při výukových a vzdělávacích aktivitách jak v rámci armády, tak u jednotlivých složek zapojených do IZS s důrazem na hasičský záchranný sbor, policii ČR a neziskové organizace. Tento úkol je postupně naplňován již dnes, a to především směrem $\mathrm{k}$ neziskovým organizacím.

- Rozvíjet a postupně předcházet od náhodných nebo jednoúčelových společných akcí zainteresovaných stran k pevně stanoveným a systematizovaným vztahům. Př́íprava a výcvik složek CIMIC musí např́iklad postupně obsahovat společná cvičení s nevládními organizacemi a složkami, které se podílí na přípravě a vzdělávání jejich pracovníků. Navést systém do společné př́ípravy, stanovit její jasné cíle, obsah a metody. Spolupráci postupně rozšiřovat na další složky.

- Dosáhnout nekonfliktnosti mezi účastníky, založené na principu vzájemného sdílení informací, vzájemného respektu a transparentnosti. Pravděpodobně nejdůležitější a nejcitlivější úkol. K jeho naplnění bude nezbytné uzavř́it řadu dílčích dohod vedoucích $\mathrm{k}$ navedení systému, jasnému stanovení časového a obsahového schématu vzájemného sdílení informací atd. Tento úkol je jedním z mnoha, které nelze vymezovat jen na fázi přípravy a výcviku, ale prolíná i do vlastního naplnění úkolů CIMIC v ,akci“.

\section{Předpokládané úkoly CIMIC při řešení krizí na vlastním území}

Na předešlém obrázku je znázorněna šíře činnosti CIMIC ve spojení s použitím OS v rámci IZS. Ze zkušeností, které získali př́slušníci střediska CIMIC př̀i plnění úkolů v zahraničí, ale především při zapojení do řešení krizových situací na vlastním území v uplynulých letech, vyplývá několik základních problémů, se kterými se setkává armáda působící v civilním prostředí. Ty lze vyčíslit v několika základních bodech:

faktická (praxí ověřená) neakceptace role ozbrojených sil, dané zákony vyhláškami a nařízeními patřičných orgánů, představiteli místní správy a samosprávy,

$\square$ nejasněné rozhraní mezi úkoly civilních organizací a armády při plnění humanitárních úkolů,

$\square$ vzájemná neznalost postupů a metod práce jednotlivých aktérů,

$\square$ problémy v koordinaci aktivit,

vzájemná neinformovanost mezi jednotlivými aktéry, včetně obyvatel a místních autorit,

zkreslování informací předávaných třetí straně (médiím),

๑ nedostatečné naplňování vzájemných závazků vyplývajících z uzavřených dohod,

vyžadování ozbrojených sil k činnostem, ke kterým nemají mandát atd.

Z tohoto stručného a neúplného výčtu plyne, že existuje široká škála standardních, ale i nových úkolů pro CIMIC, které budou v každém typu činnosti ozbrojených sil propojeny s aktivitami, zájmy a cíli vojenských a nevojenských složek. Problémy, se kterými se ozbrojené síly př́i plnění svých úkolů v civilním prostředí setkávají, mohou $\mathrm{v}$ extrémním př́ípadě vést $\mathrm{k}$ nesplnění nebo opožděnému naplnění některého 
dílčího cíle, a tím k ohrožení či oddálení vyřešení mimořádné události. CIMIC může významně napomoci při předcházení konfliktů či k jejich rychlému vyřešení. Některé z problémů může pomoci vyřšsit již dnes, na další se musí v rámci svého výcviku připravit. Škála úkolů, kterými lze pověřit orgány CIMIC, je však mnohem širší, než bylo výše nastíněno.

\section{Závěr}

Evropská unie používá takřka všechny plánovací procedury NATO, řídí se jimi, což v praxi znamená i přejímání filozofie CIMIC. EU, stejně jako NATO, zdůrazňuje význam tzv. komplexního př́istupu, comprehensive approach (CA), který se tak téměř ztotožňuje s CIMIC. Přitom CA je strategická záležitost vycházející z předpokladu, že pro úspěch v operaci je třeba využít všech dostupných nástrojů, politických, diplomatických, ekonomických, právních, a až na poslední místě vojenských. Naproti tomu CIMIC je záležitost operační a taktická, kdy jde především o vytvoření příznivých podmínek veliteli v prostředí, ve kterém vede jemu určenou operaci a plní stanovené cíle.

Současné operace, zejména jejich stabilizační fáze, se odehrávají v sociálním prostředí. V Afghánistánu se bojuje v horách, jinde na poušti, v lese, na moři i ve vzduchu, ale největším problémem jsou aktivity mezi civilní populací, při její každodenní činnosti. Zde je právě zesilována role CIMIC - čili spolupráce mezi zasahujícími vojsky a civilní sférou. Toto je nový trend vojenského výzkumu v USA, ale i v dalších zemích.

Jednou ze základních podmínek změn v přistupu k vedení současných a pravděpodobně i budoucích vojenských operací je zdokonalený přístup k civilně-vojenské spolupráci. Vzhledem k měnícímu se prostředí, ve kterém se tyto operace vedou, je tento krok - s ním související celá řada úkolů a opatření - nezbytný. To není jen otázka ozbrojených sil, které procházejí neustálými změnami souvisejícími s měnícím se zdrojovým rámcem (tento problém je společný pro většinu ozbrojených sil zemí Aliance), ale obecně platný a nezbytný požadavek.

To, co platí pro působení armád Aliance v zahraničních operacích pod společným velením, platí téměř bezezbytku v operacích na vlastním území s přihlédnutím na národní specifika daná rozdíly v legislativě řšící krizový management.

Uvedená opatření vycházejí z analýz aliančních dokumentů a z dlouhodobé zkušenosti autorů s touto problematikou. Bez změny v pojetí CIMIC, bez aplikace uvedených a pravděpodobně i celé řady dalších opatření nebudeme schopni v rámci národních armád dlouhodobě kooperovat nejen mezi sebou, ale hlavně se stále rostoucí řadou nevojenských subjektů působících v prostoru vedení vojenských operací. To s sebou přinese nutnost zpracovat celou řadu nových dokumentů řešících úkoly v nebývalé šíríi.

Tyto materiály musí být dostatečně pružné, ale i konkrétní, tak aby postihovaly co nejširší škálu standardních scénářů, se kterými se může pracovník CIMIC, ale i obyčejný voják setkat. Při jejich koncipování však nesmíme zapomínat na základní postulát a tím je, že civilně-vojenská spolupráce není pouze záležitostí specialistů CIMIC, ale hlavně velitelů na všech stupních, stejně jako jejich podřízených, kteří se pohybují mimo vojenskou základnu. A to doma i mimo vlastní území! 


\section{Literatura:}

[1] ŠEDIVÝ, Jiří. Válka: rámec pro analýzu. Dostupné na http://prg.xf.cz/kniha/kap7.htm (14.6. 2011), S. 12.

[2] KAGAN, Frederick W. The U.S. Military's Manpower Crisis. Foreign Affairs, vol. 85, No 4, July/ August 2006.

[3] Allocution du CEMAT. Dostupné na http://www.defense.gouv.fr/terre/actu-terre (26. 6. 2007).

[4] NATO. Strategic Concept. Dostupné na http://www.nato.int/lisbon2010/strategic-concept-2010-eng. pdf, p. 6-7 (20. 12. 2011).

[5] NATO. AJP-9, Allied Joint Doctrine for Civil-Military Cooperation [study draft], chapter 0201.

[6] NATO. AJP-9, Allied Joint Doctrine for Civil-Military Cooperation [study draft] chapter 0203.

[7] Ústavní zákon České republiky č. 110/1998 Sb. čl. 3 odstavec 1, Praha, 1998.

[8] NATO. AJP-9, Allied Joint Doctrine Civil-Military Cooperation [study draft]. Norfolk: ACT, 2010, p. 2-3.

Všechna opatření, která jsem zmínil, podepřená nezbytnou podporou politické reprezentace naší země a pokud možno stabilním rozpočtem, nejméně po dobu následujících tří let, nám umožní alespoň udržení stávajících schopností armády, v žádném případě nám však neumožní odstranění deficitu z let minulých, natož pak rozvoj. Už několik let velení armády upozorňuje, že jsme na hranici a někde i pod hranicí udržení schopnosti plnit celé spektrum úkolů. Je nutné si přiznat realitu v plné nahotě, at je jakkoliv nepř́ijemná. K tomu, abychom mohli zabezpečit celou škálu činností a schopností armády, včetně plnohodnotného plnění všech úkolů plynoucích ze zákonů, mezinárodních závazků a dohod, bychom potřebovali o miliardy korun ročně více, než máme dnes. Pokud by nastala krajní situace a bylo nutné armádu použít k plnění více úkolů současně, ukázalo by se, že již není odkud brát.

Na druhou stranu armáda nikdy nesmí a rozhodně nechce rezignovat na svůj hlavní úkol - zajištění obranyschopnosti naší země, a proto musí být připravena i na ten nejhorší scénářr. Peníze nám nikdo za současné situace nepřidá. Jedinou cestou k dosažení potřebné rovnováhy tak je zefektivnění armády jako celku, jejích struktur a procesů a zajištění její potřebné akceschopnosti.

Musíme všichni přispět k rožšriření obecného povědomí občanů této země, že nežijeme v době, kdybychom si mohli dovolit obranu a armádu nemít. Chci, aby veřejnost věděla, že vojáci odvádějí a jsou připraveni odvádět i nadále dobrou a profesionální práci v extrémně náročných podmínkách, at už u nás doma např. při odstraňování následků živelních katastrof, nebo v operačním nasazení daleko za hranicemi. S pomocí vás všech udělám vše pro to, aby se armáda i za těchto limitujících podmínek nestala svojí vlastní karikaturou, ale aby zůstala schopnou složkou, která bude respektovaná jak partnery v NATO, tak svým vlastním obyvatelstvem. To na ni dnes, podle mého názoru, může být právem hrdé.

Rozsah změn a proměnných $\mathrm{v}$ př́šstím roce bude vytvářet na personál extrémní tlak. Apeluji na vás - velitelský sbor, i když nebude mít vždy po ruce úplné informace, vysvětlujte vojákům přijímané kroky a opatření a nenechávejte je v nejistotě. Je potřeba, aby lidé věděli, co je čeká, v tom dobrém i v tom horším, a měli dostatek času se s realitou vyrovnat a rozhodnout se, co dál. Motivujte je, protože stále ještě je na čem stavět a bez schopných a odhodlaných profesionálů naše armáda upadne dříve než na nedostatek peněz!

\section{Generálporučík Petr Pavel, náčelník GŠ AČR, na velitelském shromáždění 8 . 11. 2012,}

http://www.acr.army.cz/informacni-servis/zpravodajstvi/velitelske-shromazdeni:projev-nacelnika-generalniho-stabu-acr-generalporucika-petra-pavla-76678/ 